\title{
Late Turonian Microfossils and Paleoclimate in the Songliao Basin, NE China
}

\author{
Ying Cui1,2, Dangpeng Xi' ${ }^{*}$, Zuohuan Qin², Xiaoqiao Wan ${ }^{2}$ \\ ${ }^{1}$ Normal College, Shenyang University, Shenyang, China \\ ${ }^{2}$ State Key Laboratory of Biogeology and Environmental Geology, China University of Geosciences, Beijing, China \\ Email: *xdp1121@163.com
}

How to cite this paper: Cui, Y., Xi, D.P., Qin, Z.H. and Wan, X.Q. (2019) Late Turonian Microfossils and Paleoclimate in the Songliao Basin, NE China. Open Journal of Geology, 9, 605-608.

https://doi.org/10.4236/ojg.2019.910053

Received: August 16, 2019

Accepted: September 20, 2019

Published: September 23, 2019

Copyright (c) 2019 by author(s) and Scientific Research Publishing Inc. This work is licensed under the Creative Commons Attribution International License (CC BY 4.0).

http://creativecommons.org/licenses/by/4.0/

(c) (i) Open Access

\begin{abstract}
Although the paleoclimate of the marine Cretaceous has been well studied, the paleoclimate of the non-marine is still not well understood. The Songliao Basin was one of the largest non-marine rift basins during Cretaceous. The Well-preserved Cretaceous lacustrine deposits in this basin provide a unique opportunity to study terrestrial paleoenvironments and paleoclimate during the Late Cretaceous. Here, the microfossils from the Late Turonian Qingshankou Formation of the Songliao Basin were used to investigate the paleoenvironments and paleoclimate of east Asia. There are two spore and pollen assemblages recognized: a Cedripites-Cyathidites-Classopollis assemblage from Upper Member 1, and a Cedripites-Cyathidites-Classopollis assemblage from Lower Member 2 of the Qingshankou Formation, respectively. Besides, relatively abundant ostracods have been identified. In the Songliao Basin, the climate was relatively warm and wet during Late Turonian, with good source rock deposited in the Songliao lake.
\end{abstract}

\section{Keywords}

Cretaceous, Songliao Basin, Spore and Pollen, Paleoclimate

\section{Introduction}

The Songliao Basin was one of the largest non-marine rift basins during Cretaceous [1]. Widespread deposits in the basin are mainly composed of clastic sediments which contain abundant fossils, such as spore and pollen, clam shrimps, ostracods, gastropod, bivalves and vertebrates. These spore and pollen fossils provide us valuable information about Cretaceous climate changes and biotic responses in a greenhouse environment. Although the paleoclimate of the marine Cretaceous has been well studied [2] [3], the paleoclimate of the non-marine is 
still not well understood. The Well-preserved Cretaceous lacustrine deposits in this basin provide a unique opportunity to study terrestrial paleoenvironments and paleoclimate during the Late Cretaceous [4] [5]. Here, the microfossils from the Late Turonian Qingshankou Formation of the Songliao Basin were used to study the paleoenvironments and paleoclimate of East Asia.

\section{Materials and Methods}

The samples were collected from Upper Member 1 to Lower Member 2 of the Qingshankou Formation of the Lijiatuozi section in the Songliao Basin. Analyses of spore and pollen and ostracod samples were carried out in the microfossil laboratory. The organic residues recovered were sieved through a $10 \mu \mathrm{m}$ mesh screen, after which they were boiled in potassium hydroxide solution $(\mathrm{KOH}$, $10 \%$ ) for $10 \mathrm{~min}$ to remove soluble humic substances. The sieved residues were strewn mounted on glass slides using epoxy. The slide numbers were prefixed 'mg' for Well Mao-206 which is another name of SK1(S). In case of less productive samples, we prepared another four slides to scan and count.

\section{Results and Discussion}

Preliminary analysis of spore and pollens, as well as ostracods from the Upper Member 1 to Lower Member 2 of the Qingshankou Formation has been taken. Two spore and pollen assemblages have been recognized. Cedripites-Cyathidites-Classopollis assemblage is belong to Upper Member 1 of the Qingshankou Formation, including Cyathidites, Schizaeoisporites, Cicatricososporites, Lygodioisporites, Balmeisporites, Cedripites, Podocarpidites, Classopollis, Pinuspollenites, Abiespollenites, Piceaepollenites, Quercoidites, Chenopodipollis and a few other taxa. Cedripites-Cyathidites-Classopollis assemblage is belong to Lower Member 2 of the Qingshankou Formation, including Schizaeoisporites, Foraminisporis, Cedripites, Classopollis, Taxodiaceaepollenites, Rugubivesiculites, Psophosphaera, Cycadopites, Quercoidites, Callistopollenites, Salixipollenites, Beaupreaidites, Tricolporopollenites, and a few other taxa. The spore and pollen fossils suggest that the climate was relatively warm and wet during this period (Late Turonian), but a little dry during sedimentation of the Lower Member 2 of the Qingshankou Formation. Beside the spore and pollens, the ostracods fossils have been identified, including Cypridea dekhoinensis, C. gibbosa, C. bistyloformis, C. tuberculata, C. adumbrata, $C$. aff. adumbrata, $C$. nota, $C$. fuyuensis, Triangulicypris tosuosus var. nota, $T$. virgate, $T$. torsuosus, T. fertilis, T. similis and Limnocypridea, suggesting a fresh to slightly brackish water environment.

The Upper Member 1 to Lower Member 2 of the Qingshankou Formation has been dating as Late Turonian [6] [7] [8] [9]. The global paleoclimate was suggested to hot during this period [2]. Based on the core of SK1(s) from the Songliao Basin, a detailed study of spore and pollen suggested a relatively warm and wet climate during Late Turonian [5], which is consistent with our results. Dur- 
ing Late Turonian (Upper Member 1 to Lower Member 2 of the Qingshankou Formation), the Songliao lake was deep in central part, but relatively shallow in marginal part, with good source rock deposited in the central part of this large lake. The spore and pollens suggested that a relatively warm and wet paleoclimate in East Asia during Late Cretaceous.

\section{Conclusion}

Relatively abundant spore and pollen, as well as ostracods have been discovered in the Lijiatuozi section of the Upper Member 1 to Lower Member 2 of the Qingshankou Formation, including two spore and pollen assemblages and one ostracod assemblage. In the Songliao Basin, the climate was relatively warm and wet during Late Turonian, with good source rock deposited in the central part of the Songliao lake.

\section{Acknowledgements}

This work was supported by Key Project of Natural Science Foundation of Liaoning Province (20170520304), the National Natural Science Foundation of China (41688103, 41790452), the Program of China Geological Survey (DD20190009, DD20160207). This is a contribution to UNESCO-IUGS IGCP Project 679.

\section{Conflicts of Interest}

The authors declare no conflicts of interest regarding the publication of this paper.

\section{References}

[1] Feng, Z., Jia, C., Xie, X., Zhang, S., Feng, Z. and Cross, T. (2010) Tectonostratigraphic Units and Stratigraphic Sequences of the Nonmarine Songliao Basin, Northeast China. Basin Research, 22, 79-95. https://doi.org/10.1111/j.1365-2117.2009.00445.x

[2] Huber, B., Norris, R. and Macleod, K. (2002) Deep-Sea Paleotemperature Record of Extreme Warmth during the Cretaceous. Geology, 30, 123-126. https://doi.org/10.1130/0091-7613(2002)030<0123:DSPROE >2.0.CO;2

[3] Sketon, P.W., Spicer, R.A., Kelly, S.P. and Gilmour, I. (2003) The Cretaceous World. Cambridge University Press, Cambridge, $360 \mathrm{p}$

[4] Wang, C.S., Feng, Z.Q., Zhang, L.M., Huang, Y.J., Cao, K., Wang, P.J. and Zhao, B. (2013) Cretaceous Paleogeography and Paleoclimate and the Setting of SKI Borehole Sites in Songliao Basin, Northeast China. Palaeogeography, Palaeoclimatology, Palaeoecology, 385, 17-30. https://doi.org/10.1016/j.palaeo.2012.01.030

[5] Zhao. J., Wan, X.Q., Xi, D.P., Jing, X., Li, W., Huang, Q.H. and Zhang, J.Y. (2014) Late Cretaceous Palynology and Paleoclimate Change: Evidence from the SK1 (South) Core, Songliao Basin, NE China. Science China Earth Sciences, 57, 2985-2997. https://doi.org/10.1007/s11430-014-4975-4

[6] Wan, X., Zhao, J., Scott, R.W., Wang, P., Feng, Z., Huang, Q. and Xi, D. (2013) Late Cretaceous Stratigraphy, Songliao Basin, NE China: SK1 Cores. Palaeogeography, 
Palaeoclimatology, Palaeoecology, 385, 31-43.

https://doi.org/10.1016/j.palaeo.2012.10.024

[7] Wu, H., Zhang, S., Jiang, G., Hinnov, L., Yang, T., Li, H., Wan, X. and Wang, C. (2013) Astrochronology of the Early Turonian-Early Campanian Terrestrial Succession in the Songliao Basin, Northeastern China and Its Implication for Long-Period Behavior of the Solar System. Palaeogeography, Palaeoclimatology, Palaeoecology, 385, 55-70. https://doi.org/10.1016/j.palaeo.2012.09.004

[8] Xi, D., Wan, X., Li, G. and Li, G. (2019) Cretaceous Integrative Stratigraphy and Timescale of China. Science China Earth Science, 62, 256-286. https://doi.org/10.1007/s11430-017-9262-y

[9] Deng, C.L., He, H.Y., Pan, Y.X. and Zhu, R.X. (2013) Chronology of the Terrestrial Upper Cretaceous in the Songliao Basin, Northeast Asia. Palaeogeography, Palaeoclimatology, Palaeoecology, 385, 44-54. https://doi.org/10.1016/j.palaeo.2012.07.028 